\title{
DETERMINANTS OF TRANSFER PRICING
}

\author{
Nia Anggraeni \\ Faculty of Economics and Business, Wijaya Putra University, Surabaya \\ niagemini19@gmail.com \\ Novrida Qudsi Lutfillah \\ Faculty of Economics and Business, Wijaya Putra University, Surabaya \\ vridaoayu@gmail.com
}

\begin{abstract}
Transfer pricing is an effort to minimize the tax burden by allocating corporate profits to the relations company with lower tax rates. This research aimed to analyze the effect of corporate governance, tunneling incentive and sales growth to practices transfer pricing. Quantitative method and secondary data of annual report. The populations in this research are manufacturing company sector basic and chemical industrial listed on the Indonesia Stock Exchange (BEI) for years 2014-2017 totaling 13 sample companies selected by purposive sampling method.The analysis technique data used is a binary logistic regression.The results of this research indicates that the variable corporate governance and sales growth not effect on practice transfer pricing, while tunneling incentive positive effect on practice transfer pricing.
\end{abstract}

Keywords: corporate governance, tunneling incentive, sales growth, transfer pricing.

\section{Research Background}

As for developing countries like Indonesia, nowadays the development of the economy is increasingly fast without boundaries. It makes the trade between countries easier and smoother which could be seen from the amount of companies began to expand its market by establishing a subsidiary in the country or abroad. However, tax regulations for multinational companies are no longer in line with global business changes across countries, ease of business mobility, increasing complexity of corporate structures and legal systems between countries including taxation rules, namely differences in tax rates that apply in each country (Mardiasmo 2017). Rosa et al. (2017) said the transaction of international trade may involve multinational business group to become more complex not only in the form of transactions in goods but also capital and immovable property and indication for tax evasion to minimize the amount of taxes through the practice of transfer pricing, that is the way to increase the purchase price or reduce sales prices within the company. The purpose of multinational companies conduct transfer pricing are transferring gains or income earned to affiliated companies located in other countries, so that the burden of corporate tax will be lower and profits are magnified by the company higher. If the terms of transfer pricing manipulation, by an additional of manipulation word, is meant to refer to an activity to increase costs or degrade bill that aims to minimize the amount of the burden of tax payable (Setiawan 2014). 


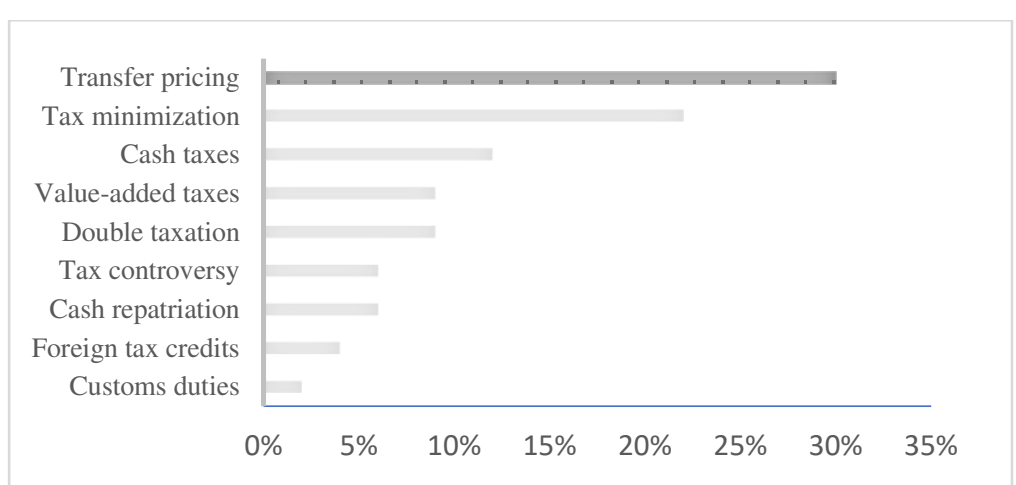

Figure 1. Taxation Issues

As shown in figure 1, Henrayana (2015) reveals in a survey by Ernt \& Youngtaxation issues related to transfer pricing become a major consideration to multinational companies. From the results of the respondents as much 35\% proved that transfer pricing issues as much as $32 \%$ showed a very critical and important thing to be faced by the company.

The company's decision to conduct transfer pricing practices can be caused by corporate governance. Good governance is able to develop company law abiding, so that the better system of corporate governance, the controls conducted by the holder of an interest will be greater to influence decision making of transfer pricing, as research conducted by Rosa, Andini, \& Raharjo (2017) and Agusto, Puspa, \& Rifa (2018) show corporate governance which is proxied by the audit quality positively significantly affect transfer pricing. However, according to Winata (2014), the positive audit quality is not significant to the tax avoidance, including the practice of transfer pricing.

The amount of incentives obtained by shareholders will do tunneling, the greater the tunneling the transfer pricing opportunity increases as research by Marfuah and Azizah (2014) and Santosa and Suzan (2018) show that tunneling incentives have a positive significant effect on transfer pricing. However, according to Rosa, Andini, \& Raharjo (2017) tunneling incentive has significant negative result towards transfer pricing. Finally, growth of selling numbers gave impact to minimize the tax burden and the company will choose the practice of transfer pricing, as well as research Rahmawati (2017) and Purwanti and Sugiyarti (2017) show sales growth positive and significant influence of tax evasion. Nevertheless, according to Noviani, Diana, \& Mawardi (2018) negative sales growth is not significant to tax avoidance.

The author's update in this study is by combining or innovating between interlaced or congruent independent and dependent variables. From the research conducted by Rosa, Andini, Raharjo (2017) the author will only re-examine the dependent variable of corporate governance, tunneling incentive to the dependent variable transfer pricing. Furthermore, the author adds one independet variable, namely sales growth, in which the greater the profit obtained, then the tax burden that must be borne by the company is also rising (Rahmawati 2017). Therefore, sales growth could affect tax evasion but the author wants to re-check the extent of the sales growth mainly on the practice of transfer pricing.

Based on the background, this research aims to test and prove the existence of corporate governance, tunneling incentives and sales growth affect the transfer pricing practice.

\subsection{Corporate Governance and Transfer Pricing}

According to Subagiastra et al. (2016), corporate governance is interconnection to the responsibilities between the shareholders, board members and commissioner including manager for the creation of a competitive performance to achieve a primary goal in the company. The shareholders wanted accurate financial statements audited by Public Accountant which one component of corporate governance is the quality of the audit because it had described how reporting matters relating to taxation on capital markets and General Meeting of Shareholders (RUPS- Rapat Umum Pemegang Saham) (Eksandy 2017). Then, the more qualified of audit in 
a company, it tended not to manipulate earnings for tax purposes, but Noviastika, Mayowan and Karjo (2016) disclosed that corporate governance did not affect the activities of irregularities, especially as a basis for decisions on transfer pricing activities, so that the results of corporate governance are positive and not significantly affect transfer pricing.

$\mathrm{H}_{1}$ : Corporate governance doesnot significantly affect the practice of transfer pricing.

\subsection{Tunneling Incentive and Transfer Pricing}

According to Mispiyanti (2015), tunneling incentive is an activity of transferring assets and profits of the company for the benefit of the majority, but the minority also bear the cost the burden that come out. Minority shareholders and other external parties are often disadvantaged by controlling shareholders because of the strong influence of the risk of exploitation, such as conglomerate business groups to control the business activities of the controlling party will lead to tunneling activities. Tunneling with parties that have a special relationship where when receivables increase can be interpreted as an increase in profits (Marfuah and Azizah, 2014). The majority shareholders would make a way to generate high profits one of the ways is by transfer pricing (Saraswati and Sujana, 2017). Shareholders with a large ownership in the company, the expected return on dividends are also large so that it triggers transfer pricing (Santosa and Suzan, 2018). As result, it can reveal tunneling incentives that significantly affect transfer pricing.

$\mathrm{H}_{2}$ : Tunneling incentive significantly influences the practice of transfer pricing.

\subsection{Sales Growth and Transfer Pricing}

According to Kennedy and Zuzana (2013), sales growth illustrates the level of increase in the number of sales from period year to year or from time to time. Negative sales growth indicates a decline in operating activities that have an impact on lowering company profits. The higher sales growth, it will affect a growing number of tax avoidance through transfer pricing. It is because of the level of sales are relatively large, so it will provide opportunities companies to obtain greater profits (Dewinta and Setiawan 2016). A large profit makes the tax burden even greater by the company (Purwanti and Sugiyarti 2017). Then, it can reveal significant positive sales growth affecting transfer pricing .

$\mathrm{H}_{3}$ : Sales growth significantly influences the practice of transfer pricing.

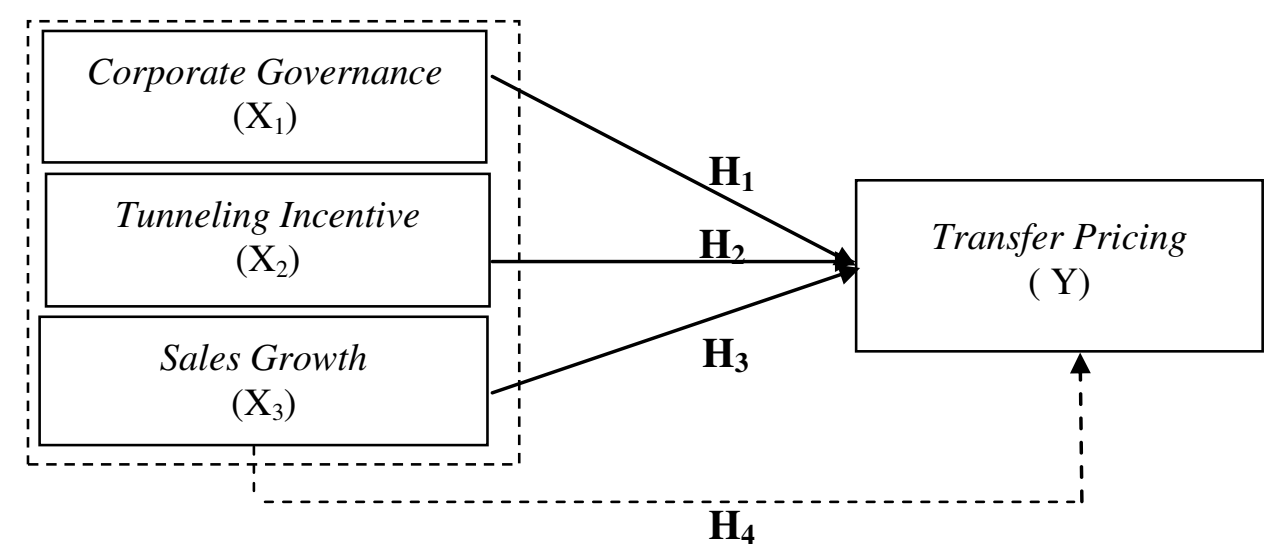

Figure 2. Conceptual Framework

Details :

$\longrightarrow=$ partial

$\longrightarrow-\cdots=$ simultan

\section{Research Method}

This research is categorized as a quantitative research for this research is presented by 
numbers and described descriptively. The type of data analyzes secondary data by using Annual Report. The population in this experiment is a basic manufacturing company and chemical industry sectors listed on the Indonesia Stock Exchange (BEI) in 2014-2017 through the official website that could be accessed on www.idx.co.id. The technique of sampling is purposive sampling in which the decision criteria of the sample has been set by the researcher. Sugiyono (2016) set the following criteria:

1. The basic and chemical industrial companies listed on the Indonesia Stock Exchange in 2014-2017.

2. The basic and chemical industry companies were successively listed on the Indonesia Stock Exchange in 2014-2017.

3. The basic and chemical industry companies successively submitted the 2014-2017 annual report.

4. Basic and chemical industry companies present financial statements in rupiah.

5. Basic and chemical industrial companies are controlled by foreign company shares propietary as much as $20 \%$.

6. The company experienced delisting during 2014-2017.

Therefore, the sample of this research are 13 companies with four years of observation, by that the sample size is 52 . Here is the list of companies manufacturing base and chemical industry sectors which is used as the research samples.

Table 1. Sample of Companies

\begin{tabular}{|c|c|l|}
\hline No & Issuer Code & \multicolumn{1}{|c|}{ Company name } \\
\hline 1 & INTP & PT Indocement Tunggal Prakarsa Tbk. \\
\hline 2 & SMCB & PT Holcim Indonesia Tbk. \\
\hline 3 & AMFG & PT Asahimas Flat Glass Tbk. \\
\hline 4 & IKAI & PT Intikeramik Alamasri Industri Tbk. \\
\hline 5 & KIAS & PT Keramika Indonesia Assosi Tbk. \\
\hline 6 & TOTO & PT Surya Toto Indonesia Tbk. \\
\hline 7 & LION & PT Lion Metal Works Tbk. \\
\hline 8 & LMSH & PT Lionmesh Prima Tbk. \\
\hline 9 & PICO & PT Pelangi Indah Canindo Tbk. \\
\hline 10 & ETWA & PT Eterindo Wahanatama Tbk. \\
\hline 11 & JPFA & PT Japfa Comfeed Indonesia Tbk. \\
\hline 12 & PLAY & PT Malindo Feedmill Tbk. \\
\hline 13 & Indonesian & PT Kertas Basuki Rachmat Indonesia \\
& Embassy & Tbk. \\
\hline
\end{tabular}

The dependent variable of this study is transfer pricing . This dummy variable is assessed by 2 alternatives, namely related party sales and non-related party sales. Since. the sales price that is set is usually overriding the principle of fairness. The company has a sales transaction to a related party ( rated) is given a value of 1 , while given a value of 0 for the company which there is no sales transaction to a related party (related).

The independent variable used is corporate governance proxied by audit quality, where companies audited by The Big Ten Public Accounting Firm are considered better including, PriceWaterhouse Cooper - PWC KAP Haryanto Sahari, Deloitte Touche Tohmatsu KAP Osman Bing Satrio, KMPG KAP Sidharta \& Sidartha Widjaja, Ernest \& Young - E\&Y KAP Purwanto Sarwoko Sandjaja, RSM AAJ Mc Gladrey \& Pullen, Grant Thornton, CBIZ Mayer Hoffman Mc Cann, BDO USA, Crowe Horwath and BKD. Then, the value of 1 audited by KAP The Big Ten, while value 0 audited by KAP nonThe Big Ten.

Tunneling incentive is proxied by their manufacturing company which under the control of a foreign company by having the ownership interest is $\geq 20 \%$. The entity is deemed significant to influence directly or indirectly if it includes ownership of $20 \%$ or more in 
accordance with Statement of Financial Accounting Standards (PSAK) No. 15 of 2013.

Sales growth is a sales ratio that can determine a company's profitability and generate profits measured by using an indicator of a company's sales transaction can be calculated with the following formula:

salest $=$ sales in the current period

$$
\text { Sales ratio }=\frac{\text { sales }_{t}-\text { sales }_{t-1}}{\text { sales }_{t-1}}
$$

salest $-1=$ sales in the previous period

Data analysis in this study uses logistic regression analysis or commonly called binary logistic regression, namely logistic regression where the dependent variable is a kotomi variable which only has two categories and is vulnerable to values between 0 and 1 . The dependent variable, transfer pricing, is the dichotomous variable of this study. Thus, the logical regression equation model is typed :

Information:

$$
\log (P / 1-p)=a+\beta 1 X_{1}+\beta 2 X_{2}+\beta 3 X_{3}+\varepsilon
$$

$\mathrm{P}=$ possibility of $\mathrm{Y}($ transfer picing $) \quad \mathrm{X}_{1}=$ corporate governance

$\mathrm{a}=$ constant $\quad \mathrm{X}_{2}=$ tunneling incentive

$\mathrm{B}=$ regression coefficient $\quad \mathrm{X}_{3}=$ sales growth

$\varepsilon=$ error

\section{Result and Discussion}

\subsection{Results of Data Analysis}

In this research, there is a dummy variable, so it uses descriptive statistical analysis of frequency, which describes the data in quantitative form with the response distribution of each determination ( 1 or 0 , yes or no, etc.). The research uses descriptive statistics frequency to see an overview of corporate governance variables $\left(\mathrm{X}_{1}\right)$ and transfer pricing $(\mathrm{Y})$.

Table 2. Frequency Transfer Pricing

\begin{tabular}{lcc}
\hline Sales & Frequency & Percent \\
\hline Related & 44 & 84.6 \\
Unrelated & 8 & 15.4 \\
Total & 52 & 100.0
\end{tabular}

The results of descriptive analysis of table 2 , there are $84.6 \%$ of sample companies with sales transactions to related parties, and the remaining $15.4 \%$ no sales transactions to related parties. This shows that most of the sample companies practice transfer pricing by selling to related parties in planning the tax burden in the company.

Table 3 . Frequency of Corporate Governance

\begin{tabular}{lcc}
\hline KAP The Big Ten & Frequency & Percent \\
\hline NO & 33 & 63.5 \\
YES & 19 & 36.5 \\
Total & 52 & 100.0
\end{tabular}

The results of descriptive analysis in table 3 shows that $63.5 \%$ of the sample companies were not audited by the Big Ten Public Accounting Firm, while 36.5\% were audited by The Big Ten Public Accounting Firm. This shows that most of the sample companies are still weak in considering their financial statements to be audited by The Big Ten KAP auditors, so that the possibility of fraud could have occurred without close and good supervision from the auditor.

Table 4. Results of Analysis Deskriptif

\begin{tabular}{lccccc}
\hline Variable & N & Min & Max & The mean & Std. Deviation \\
\hline Tunneling Incentive & 52 & 21,830 & 96,310 & 47,52596 & 22.802579
\end{tabular}




\begin{tabular}{llllll} 
Sales Growth & 52 &,- 841 & 5,947 &, 09362 &, 902670 \\
$\mathrm{~N}$ & 52 & & & \\
\hline
\end{tabular}

Descriptive analysis Table 4 result shows tunneling incentive sample companies during 2014 to 2017 has the lowest value of 21.83 from PT Eterindo Wahanatama Tbk. (ETWA) and the highest value of 96.31 was obtained from PT Keramika Indonesia Association Tbk. (KIAS) with an average value of 47.5260 and a standard deviation of 22.80258 .

The sample company's sales growth during 2014-2017 has the lowest value of -0.841 and the highest value of 5.947 with an average value of 0.9362 and a standard deviation of 0.902670 .

Table 5. Multicollinearity Test Results

\begin{tabular}{lcc}
\hline Independent Variable & $\begin{array}{c}\text { Collinearity } \\
\text { Tolerance }\end{array}$ & $\begin{array}{c}\text { Collinearity } \\
\text { VIF }\end{array}$ \\
\hline Corporate Governance & 0.876 & 1,141 \\
Tunneling Incentive & 0.880 & 1,136 \\
Sales Growth & 0.992 & 1,008 \\
\hline
\end{tabular}

As the results of the tolerance value $>0.10$ and the value of the inflation factor $(\mathrm{VIF})<10$, it shows that the independent variable is free from multicollinearity.

Table 6. Hosmer and Lemeshow Test Results

\begin{tabular}{lccc}
\hline Step & Chi-square & $D f$ & Sig. \\
\hline 1 & 5,418 & 8 &, 712 \\
\hline
\end{tabular}

With the results of Chi-square value of 5.418, degrees of freedom (df) 8 with a significant value of 0.7120 .05 , the hypothesized regression model that was fit is accepted because it matched with the observational data.

Table 7. Overall Model Fit Test Results

\begin{tabular}{lcc}
\hline Step & -2 Log likelihood & Constant \\
\hline 0 & 44,650 & 1,705 \\
1 & 28,661 & $-4,542$ \\
\hline
\end{tabular}

With the results of the value of $-2 \log$ likelihood 0 of 44,650 and after entering the independent variable corporate governance $\left(\mathrm{X}_{1}\right)$, tunneling incentive $\left(\mathrm{X}_{2}\right)$, sales growth $\left(\mathrm{X}_{3}\right)$ value of -2 Log likelihood 1 to 28,661. Decreasing in value of -2 Log likelihood indicates that a good regression model is hypothesized fit with the data.

Table 8. Classification Table Test Results

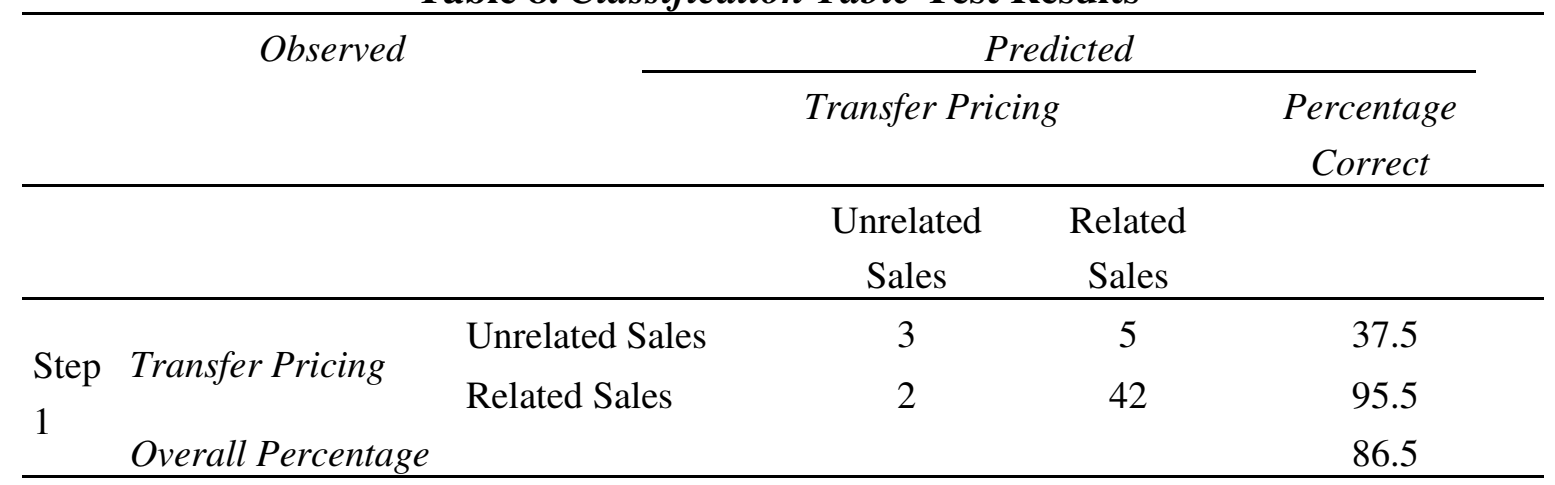

a.

The cut value is, 500

Based on the results of table 8 , the predictive power of the regression model for the probability of transfer pricing practices is $86.5 \%$, there are 42 companies or $95.5 \%$ of companies that are predicted to make transfer pricing decisions from a total of 44 companies 
that do transfer pricing practices while company probabilities are not indicated transfer pricing practices, there are 3 companies or $37.5 \%$ of the total 8 companies.

\subsection{Hypothesis Test Results}

Table 9. Omnibus Test Results

\begin{tabular}{ccc}
\hline Chi-square & Df & Sig \\
\hline 15,988 & 3 &, 001 \\
\hline
\end{tabular}

The resulting Chi-Square value obtained was 15,988 and free degrees (df) of 3 with a significance of $0.001<0.05$ then involving the independent variables was declared to have a significant simultaneous effect. As result, corporate governance, tunneling incentives and sales growth have a significant effect on the practice of transfer pricing simultaneously.

Table 10. Wald Test Results

\begin{tabular}{lcccc}
\hline Variable & Coefficient & Wald & Sig & Conclusion \\
\hline CG $\left(\mathrm{X}_{1}\right)$ & 1,467 & 2,063 & .151 & Not significant \\
$\mathrm{IT}\left(\mathrm{X}_{2}\right)$ & .165 & 5,268 & 0.022 & Significant \\
$\mathrm{SG}\left(\mathrm{X}_{3}\right)$ & $-0,752$ & 1,174 & .279 & Not significant \\
Constant & $-4,542$ & & & \\
\hline
\end{tabular}

The regression equation is as follows:

$$
=-4,542+1,467 X_{1}+0,165 X_{2}-0,752 X_{3}+\varepsilon
$$

\subsection{Discussion}

\section{The effect of corporate governance on the practice of transfer pricing .}

The results of the regression equation show the relationship between corporate governance and transfer pricing is negative. The direction of the negative sign implies that if the coefficient of corporate governance increases, the practice of transfer pricing will decrease and vice versa. Partially, corporate governance can be seen in wald test amounted to 2,063 with level of significant 0.151 . It is stated corporate governance does not significantly affect the practice of transfer pricing.

Corporate governance proxied by audit quality may not affect the practice of tax evasion in the conduct of transfer pricing, since there is no significant difference between the companies audited by KAP The Big Ten and KAP non The Big Ten. Winata (2014) revealed ethics Public Accounting Firm (KAP-Kantor Akuntan Publik) audited financial statements referring to the appropriate standard of audit quality as well as the ethics of public accountants in practice based on rules set by the Board of Public Accountants Professional Standards Institut Indonesian Public Accountant.

In line with and support with Noviastika, Mayowan, \& Karjo's research (2016) revealed that the company did not consider good management as a basis for transfer pricing activities. Yet, contrary to research by Dewi and Sari (2015), Rosa, Andini, \& Raharjo (2017), Agusto, Puspa, \& Rifa (2018) revealed that corporate governance has a significant positive effect on the practice of transfer pricing.

\section{The effect of tunneling incentives on the practice of transfer pricing .}

The results of the regression equation show the relationship between tunneling incentives and transfer pricing is positive. The direction of the positive sign means that if the tunneling incentive coefficient increases, the practice of transfer pricing will increase and vice versa. Partial tunneling incentives can be seen in the Wald test of 5.268 with a significant level of 0.022 . This suggests that tunneling incentives significantly affect the practice of transfer 
pricing.

The increasing practice of tunneling incentives, the company will do more transfer pricing. Tunneling is done with related parties, the price agreement can be lower. This research is supported by research of Saraswati and Sujana (2017), because the greater the ownership of foreign shares held in the company, they automatically also want a large return or dividend as well. So when it comes to receiving dividends from minority shareholders, they prefer to do transfer pricing by transferring company assets to meet their own interests rather than dividing dividends to minority shareholders.

This study supports research conducted Marfuah and Azizah (2014), Noviastika, Mayowan, \& Karjo (2016), Santosa and Suzan (2018) results that expressed tunneling incentive positive effect significantly to transfer pricing. However,it is contrary to research by Rosa, Andini, \& Raharjo (2017) which states tunneling incentives have a significant negative effect on transfer pricing .

\section{The effect of sales growth on transfer pricing practices .}

The results of the regression equation show the relationship between sales growth and transfer pricing is negative. The direction of the negative sign implies that if the coefficient of sales growth increases, the practice of transfer pricing will decrease and vice versa. Partially sales growth can be seen in the Wald test of 1.174 with a significant level of 0.279 . This states that sales growth does not significantly affect the practice of transfer pricing.

The increase in sales growth can prove the higher the company's profits obtained, so that the company is able to maintain management not to make deviations through tax avoidance. Tax avoidance by minimizing tax burden payment is one of the practices of transfer pricing. This is in line with research Noviani, Diana, \& Mawardi (2018) which also states that sales growth has a significant negative effect on the practice of transfer pricing .

Though, it us contrary to the research of Dewinta and Setiawan (2016), Rahmawati (2017), Purwanti and Sugiyarti (2017) which stated that sales growth had a significant positive effect on tax avoidance where an increasing number of sales of companies wanted large profits but were reluctant to spend large tax costs as well so avoid tax in order to minimize the burden.

\section{Conclusion, Limitations and Suggestions}

The results of this study indicate that the corporate governance, tunneling incentive and sales growth significantly affect the practice of transfer pricing simultaneously. Corporate governance does not significantly affect the practice of transfer pricing because of audit quality KAP by The Big Ten and KAP non The Big Ten is not able to guarantee the company conduct a deviation from the rules in the decision practice of transfer pricing. Tunneling incentive significant positive influence the practice of transfer pricing for $\mathrm{p}$ eme gang controlling stake in power determine the decision so the ownership interest of foreign control, the more powerful in doing tunneling well in the practice of transfer pricing. Sales growth does not significant affect the practice of transfer pricing negatively because of the high growth in sales of the company then diminishing the efforts of tax evasion in the practice of transfer pricing. A high sales growth makes a big profit company so that it can run its tax payment obligations.

Suggestions for future researchers, other independent variables related to transfer pricing such as debt covenantscould be added. Debt covenants is considered to be more important variables in disclosure of transfer pricing because increasing report of changes in earnings causes a decrease in technical negligence so that it will choose to practice corporate earnings with transfer pricing (Rosa et al. 2017). Also, the future researcher could extend the period of the research year and use other population objects to provide better research results. While practical for the Government is expected to tighten rules on transfer pricing by adding and clarify the content of the sanction if it is found the company violated the rules made 
to reduce the abuse of the practice of transfer pricing. In addition, the company is also expected to pay more attention to every action that will be taken by shareholders, financial statement holders and risks borne related to personal interests with tax problems in the company.

This study has several limitations. Firstly, it has very limited variables consisting of only three independent variables namely corporate governance, tunneling incentives and sales growth. Second, the limitation comes from the measurement of the transfer pricing variable, which is still limited to the dichotomy using a dummy variable. The third limitation is the fouryear observation period, namely 2014-2017, which only produced 52 research samples for logistic regression which can be considered relatively small.

\section{References}

Agusto G, Puspa DF, Rifa D. 2018. Pengaruh Pajak, Mekanisme Bonus, dan Good Corporate Governance Terhadap Indikasi Melakukan Transfer Pricing. Jurnal Fakultas Ekonomi. 12 (1): $1-2$.

Dewi GAP, Sari MMR. 2015. Pengaruh Insentif Eksekutif, Corporate Risk dan Corporate Governance Pada Tax Avoidance. E-Jurnal Akuntansi Universitas Udayana. 13 (1): 50-67.

Dewinta IAR, Setiawan PE. 2016. Pengaruh Ukuran Perusahaan, Umur Perusahaan, Profitabilitas, Leverage, dan Pertumbuhan Penjualan Terhadap Tax Avoidance. E-Jurnal Akuntansi Universitas Udayana. 14 (3): 1584-1613.

Eksandy A. 2017. Pengaruh Komisaris Independen, Komite Audit, dan Kualitas Audit Terhadap Penghindaran Pajak (Tax Avoidance). Jurnal Akuntansi dan Keuangan. 1 (1): 120.

Henrayana IGY. 2015. Analisis Kasus Transfer Pricing PT Toyota Motor Manufacturing Indonesia. [Cited in April 15 2019]. Available from https://www.academia.edu/30216203.

Kennedy NA, Zuzana AR. 2013. Faktor-Faktor yang Mempengaruhi Struktur Modal pada Perusahaan Real Estate and Property yang Go Public. Jurnal Akuntansi Fakultas Ekonomi Universitas Riau.

Mardiasmo. 2017. Informasi Keuangan Bisa Deteksi Kepatuhan Pajak.[Dikutip pada 01 April 2019]. Available from http://ekonomi.inilah.com/read/detail/2405878/informasi-keuanganbisa-deteksikepatuhan-pajak.

Marfuah AAPN. 2014. Pengaruh Pajak, Tunneling Incentive dan Exchange Rate Pada Keputusan Transfer Pricing Perusahaan. Jurnal Akuntansi \& Auditing Indonesia. 18 (2): $156-165$

Mispiyanti. 2015. Pengaruh Pajak, Tunneling Incentive dan Mekanisme Bonus Terhadap Keputusan Transfer Pricing. Jurnal Akuntansi \& Investasi. 16 (01): 62-73.

Noviani L, Diana N, Mawardi MC. 2018. Pengaruh Karakteristik Eksekutif, Komite Audit, Ukuran Perusahan, Leverage dan Sales Growth Pada Tax Avoidance. Jurnal Ilmiah Riset Akuntansi Universitas Islam Malang. 7 (01): 27-40.

Noviastika D, Mayowan Y, Karjo S. 2016. Pengaruh Pajak, Tunneling Incentive dan Good Corporate Governance (GCG) terhadap Indikasi Melakukan Transfer Pricing pada Perusahaan Manufaktur yang Terdaftar Di Bursa Efek Indonesia. Jurnal Perpajakan. 8(1): $1-9$.

Purwanti SM, Sugiyarti L. 2017. Pengaruh Intensitas Aset Tetap, Pertumbuhan Penjualan dan Koneksi Politik Terhadap Tax Avoidance. Jurnal Riset Akuntansi \& Keuangan. 5 (3): 16251642.

Rahmawati L. 2017. Pengaruh Intensitas Modal, Sales Growth, dan Karakter Eksekutif Terhadap Tax Avoidance Dengan Leverage Sebagai Variabel Interviening. E-jurnal Akuntansi.

Rosa R, Andini R, Raharjo K. 2017. Pengaruh Pajak, Tunneling Insentive, Mekanisme Bonus, Debt Covenant dan Good Corperate Gorvernance (GCG) Terhadap Transaksi Transfer 
Pricing. Jurnal Ilmiah Mahasiswa S1 Akuntansi Universitas Pandanaran. 3 (3): 1-19.

Santosa DSJ, Suzan L. 2018. Pengaruh Pajak, Tunneling Incentive Dan Mekanisme Bonus Terhadap Keputusan Transfer Pricing. Jurnal Kajian Akuntansi. 19 (2): 76-83.

Saraswati GARS, Sujana IK. 2017. Pengaruh Pajak, Mekanisme Bonus, dan Tunneling Incentive Pada Indikasi Melakukan Transfer Pricing. E-Jurnal Akuntansi Universitas Udayana. 19 (2): 1000-1029.

Setiawan H. 2014. Transfer Pricing dan Risikonya Terhadap Penerimaan Negara.[Cited in Maret 19 2019] Available from http://kemekeu.go.Id.

Subagiastra K, Arizona IPE, Mahaputra INKA. 2016. Pengaruh Profitabilitas, Kepemilikan Keluarga, dan Good Corporate Governance Terhadap Penghindaran Pajak. Jurnal Ilmiah Akuntansi. 1 (2): 167-193.

Sugiyono. 2016. Metode Penelitian Pendidikan Pendekatan Kuantitatif, Kualitatif dan R\&D. Bandung: Alfabeta.

Winata F. 2014. Pengaruh Corporate Governance Terhadap Tax Avoidance Pada Perusahaan Yang Terdaftar Di Bursa Efek Indonesia Tahun 2013. Jurnal Tax \& Accounting Review. 4 (1):1-11. 